Dept. of Chemistry,

Animal Health Research Institute (Mansoura Branch)

\title{
THE INFLUENCE OF DRY AND GREEN SEASONS \\ RATION ON SOME HORMONAL AND BIOCHEMICAL PARAMETERS IN THE FOLLICULAR FLUID OF NORMAL CYCLIC NON-PREGNANT BUFFALO - COWS
}

(With 3 Tables)

By

\author{
S.S.S. YOUNIS; S.A.TAWFIK; R.A. EL-RAMADY \\ and H.A. SHALABY \\ (Received at 11/6/2008)
}

تأثير العليقة الجافة والخضراء على بعض القياسات الهرمونية والبيوكيميائية في سائل حويصلة جراف في الجاموس غير العير العثار أثناء طور الثبق الثيات

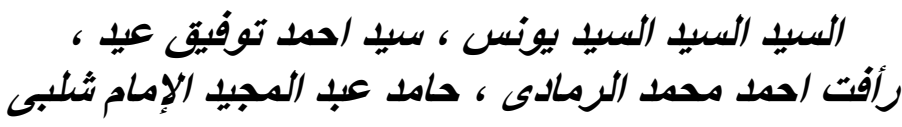

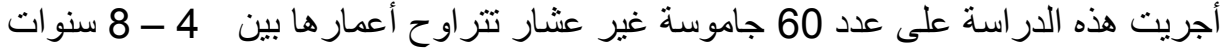
وذللك بعد الذبح و التجويف الذى تم بمجزر المنصورة محافظة الدقيلية حيث تم تم اختيار

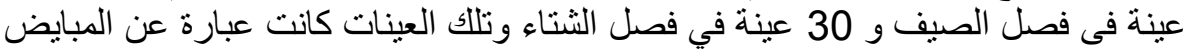

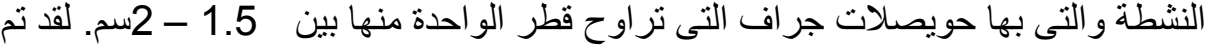

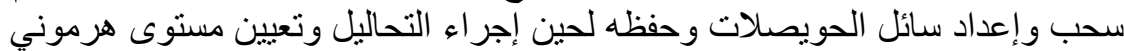

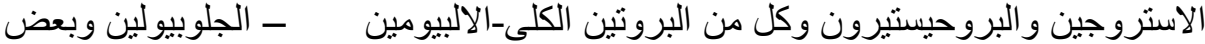

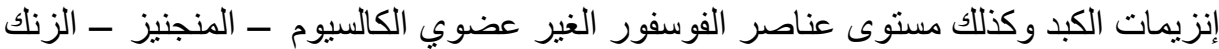

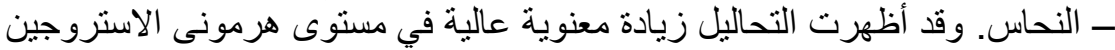

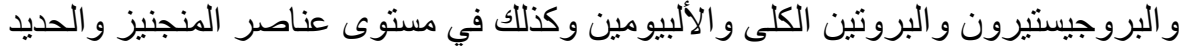

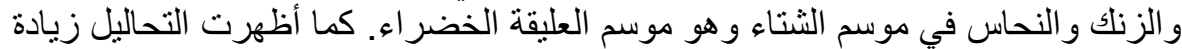

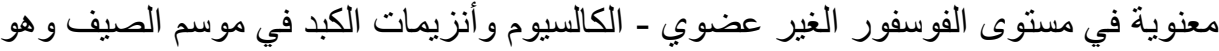

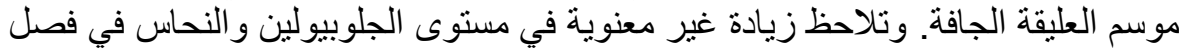

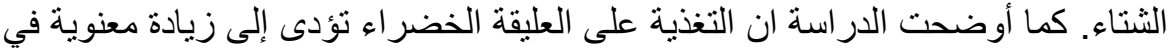

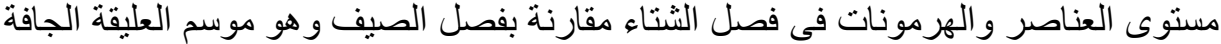

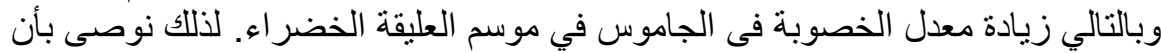

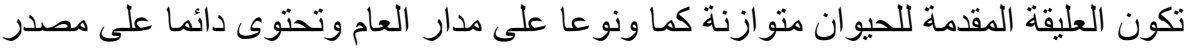
غذائي اخضر لرفع مستوى الخصوبة. 
This study was carried out on 60 ovarian samples of normal cyclic nonpregnant buffalo-cows. The experimental period extended for eight months (four months for each of dry and green seasons). The samples were collected from 60 normal cyclic non - pregnant slaughtered buffalo - cows. (30 samples during the dry seasons and 30 samples during the green one). The age of the animals was ranging between $4-8$ years old. This study was carried out to test possible the variations between some hormonal and biochemical constituents of the follicular fluid during these different seasons in normal non - pregnant cyclic. Buffalo - cows which were tested during proestrus and oestrus phases and samples were collected after slaughtering and evisceration. The study included the effect of nutrition on the determined parameters of oestrogens, progesterone, total protein, albumen, globulin, AST, ALT, inorganic phosphorus, calcium manganese, iron, Zinc and copper. The results revealed that, there was a high significant increase in both of follicular oeotrogens and progesterone during the green season than the dry one. A high significant increase in the level of total protein and albumin during the green season than the dry one. Also a non significant increase in globulin level during the green season than the dry one. The study recorded also a significant increase in transminases AST and ALT levels during the dry seasons than the green one. The results revealed a high significant increase in inorganic phosphorus level and only a significant increase in calcium level during the dry season than the green one. This study showed also a significant increase in manganese and a nonsignificant increases in zinc and copper in the follicular fluid of the buffalo - cows during oestrus phases.

Key words: Ovary, graffian follicle, estrogen, progesterone, ration

\section{INTRODUCTION}

The follicular fluid is the liquid that accumulates in the extracellular spaces within ovarian follicles (Edwards, 1974 and Mc Natty, 1978).

The follicular fluid is not a simple transudate of blood but a complex of restricted components of serum and follicular synthesized secretions, the fluid is derived from the plasma through thecal blood vessels and modified by secretions of follicular cells (Bellin and Ax., 1984). The ovaries of the cow are the major source of oestrogens and progesterone found in the peripheral blood (Kanchev et al., 1976 and 
Eissa, 1995). The reproductive insufficiency in buffaloes either directly or indirectly involves the ovarian follicles which are the main source of steroid hormones of the blood during its maturation (Hutchuson, 1993).

Seasonal changes may be caused either by changes in feeding or by changes of the ambient temperature. The longest calving intervals were noted when buffaloes gave birth during spring but the shortest intervals were observed when the animals delivered calves in autumn (Gharib et al., 1964). The Egyptian buffaloes usually suffer from ovarian inactivity during summer and return to their normal sexual activity with the onest of autumn and winter (El- Wishy, 1965; El - Shawaf, 1979 and Younis, 1995).

The sexual activity of Phillippian buffaloes was increased during the rainy cold months and decreased during high atmospheric temperature and dry months (Perry, 1969).

During the follicular phase, serum oestrogen level rises in parallel to the growth of follicle size as well as to the increasing number of granulosa cells (Naveed Khan et al., 2005).

The follicular fluid constituents are similar to blood plasma except it contains much lower level of fibrinogen and its protein, carbohydrate and steroid profile can fluctuate with the metabolic stage of the follicle (Lipner, 1988). The follicular growth and nutrition play a role in follicular estradiol production (Rone et al., 1983). The follicular fluid is in close contact with the oocyte and granualosa cells, so alterations in the concentration of its different constituents may reflect the requirements of follicular structure (Younis, et al., 1988 and Eissa, 1995). The increase of manganese and iron was by feeding on high quality of green fodders or to effect of day light period, temperature and humidify (El - Enany, 1994).

Follicular development and ovulatory process in mammals involve local biochemical changes as a result of susbstantial modifications in cellular metabdism, the most well known of which is steroid variation. (Gerard et al., 2002). The ovine follicular fluid was analyzed for glucose, total protein, calcium, phosphorus and magnesium. As follicles became larger, the concentrations increased (Nandis et al., 2007).

The aim of this study was to determine the levels of some hormonal and biochemical constituents in the follicular fluid of normal cyclic non - pregnant buffaloes and their relation to winter and summer ration. 


\section{- Clinical examination and sampling:}

Sixty pairs of buffalo ovaries were collected from the slaughter house in Mansoura city, thirty pairs during the period from August to November in the dry season and thirty pairs from January to April in the green one, 2007 - 2008 the samples were collected immediately after slaughtering and evisceration. The genitalia of 60 non - pregnant cyclic buffalo - cows aged from $4-8$ years old were collected according to the presence of the Graffian follicles at various physiological stages of its development. The chosen ovaries were placed on ice until reach, to the laboratory within 1 to 2 Hours. The ovaries were examined again and follicles were measured by using a caliper. The diameter of the follicles ranged between $1.5-2 \mathrm{~cm}$ representing the follicular stage of oestrus cycle (Sharawy, 1977).

All the protruding Graffian follicles fluid was aspirated by using $2 \mathrm{ml}$ syringe to a clean centrifuge tubes within two hours after slaughtering (El-Sawaf and Schmidt, 1962).

Samples of the follicular fluid were centrifuged at 3000 r.p.m for 15 minutes to remove the cellular debris. The supernatant fluid was kept at $-20^{\circ} \mathrm{c}$ till biochemical analysis.

- Hormonal assays:

- Oestrogen and progesterone: They were determined by radioimmuno - assay (RIA) by using RIA kits (DPC, Diagnostic corporation, Los Angelus) at Atomic Energy Authority using the method of Abraham (1977), Agthe and Kolm (1975) respectively.

\section{- Biochemical analysis:}

- Total protein, albumin and globulin: They were estimated by using atomic absorption spectrophotometer (Perkin Elemr model 3300, USA) according to Grant, et al., (1987).

- Transaminase enzymes (AST and ALT): They were determined according to Henery (1965).

- Inorganic phosphorus and calcium: They were determined by using atomic absorption spectrophotometer (Perkin Elemr model 3300, USA) according to Fraser, et al. (1987).

- Manganese, iron, zinc and copper: They were determined in the follicular fluid by using atomic absorption spectrophotometes (Perkin Elemer, model 3300, USA) as described by Meter and Henkin (1971). 


\section{Nutrition:}

The case history revealed that, the animals were fed daily with $3 \mathrm{~kg}$ concentrate mixture $+30 \mathrm{~kg}$ barseem (Trifolium alexandrinum) + sufficient amount of rice straws in the green season and during the dry one $3 \mathrm{~kg}$ of concentrate mixture $+4 \mathrm{~kg}$ of barseem hay + sufficient amount of rice straws till statisfaction.

The obtained results were statistically analysed according to the method described by Snedecor and Conhran (1980).

\section{RESULTS}

Mean values of oestrogen, progesterone and biochemical constituents of the follicular fluid of normal cyclic non- pregnant buffalo-cows (oestrus phase) during the green and the dry seasons are presented in Table, 1, 2 and 3.

Table 1: Mean values of follicular fluid steroid levels during the dry and the green seasons in buffaloes.

\begin{tabular}{|l|c|c|c|}
\hline \multicolumn{1}{|c|}{ Follicular fluid steroids } & $\begin{array}{c}\text { Green season } \\
(\mathrm{No}=30)\end{array}$ & $\begin{array}{c}\text { Dry season } \\
(\mathrm{No}=30)\end{array}$ & T value \\
\hline Oestrogens $(\mathrm{ng} / \mathrm{ml})$ & $1038.44 \pm 36.21^{* *}$ & $910.20 \pm 27.51$ & 2.8 \\
\hline Progesterone $(\mathrm{ng} / \mathrm{ml})$ & $35.26 \pm 3.27^{* *}$ & $21.18 \pm 3.21$ & 3.07 \\
\hline
\end{tabular}

** $\quad(\mathrm{P} \leq 0.01)$ High significant

$* \quad(\mathrm{P} \leq 0.05)$ significant

$\pm \quad$ Standard deviation

Table 2: Mean values of follicular fluid total protein, albumin, globulin and transaminases (AST \& ALT) in buffaloes.

\begin{tabular}{|l|c|c|c|}
\hline \multicolumn{1}{|c|}{ Follicular fluid steroids } & $\begin{array}{c}\text { Green season } \\
(\mathrm{No}=30)\end{array}$ & $\begin{array}{c}\text { Dry season } \\
(\mathrm{No}=30)\end{array}$ & $\tau$ value \\
\hline Total protein $(\mathrm{gm} / \mathrm{dl})$ & $7.98 \pm 0.26^{* *}$ & $7.29 \pm 0.16$ & 2.26 \\
\hline Albumin $(\mathrm{gm} / \mathrm{dl})$ & $4.08 \pm 0.14^{*}$ & $3.63 \pm 0.10$ & 2.61 \\
\hline Glubulin $(\mathrm{gm} / \mathrm{dl})$ & $3.90 \pm 0.12$ & $3.66 \pm 0.06$ & 1.78 \\
\hline AST (U/L) & $53.2 \pm 3.6$ & $62.7 \pm 2.0^{*}$ & 2.306 \\
\hline ALT (U/L) & $22.5 \pm 2.0$ & $33.9 \pm 2.5^{*}$ & 2.342 \\
\hline
\end{tabular}

$* * \quad(\mathrm{P} \leq 0.01)$ High significant

* $\quad(\mathrm{P} \leq 0.05)$ significant

$\pm \quad$ Standard deviation 
Table 3: Mean values of some mineral parameters of the buffalo follicular fluid during the green and the dry seasons.

\begin{tabular}{|c|c|c|c|}
\hline Follicular fluid steroids & $\begin{array}{l}\text { Green season } \\
\qquad(\mathrm{No}=30)\end{array}$ & $\begin{array}{c}\text { Dry season } \\
(\mathrm{No}=30)\end{array}$ & $\tau$ value \\
\hline Inorganic phosphorus (mg/dl) & $4.58 \pm 0.23$ & $5.72 \pm 0.27^{* * *}$ & 3.38 \\
\hline Calcium (mg/dl) & $8.92 \pm 0.47$ & $10.64 \pm 0.50^{*}$ & 2.50 \\
\hline Manganese (ug/ml) & $1.20 \pm 0.09^{* * *}$ & $0.75 \pm 0.11$ & 3.16 \\
\hline Iron $(\mathrm{ug} / \mathrm{ml})$ & $62.50 \pm 8.70^{*}$ & $32.30 \pm 7.60$ & 2.61 \\
\hline Zinc (ug/ml) & $1.58 \pm 0.08^{*}$ & $1.27 \pm 0.09$ & 2.574 \\
\hline Copper (ug/ml) & $3.08 \pm 0.10^{*}$ & $2.69 \pm 0.12$ & 2.496 \\
\hline $\begin{array}{ll}* * & (\mathrm{P} \leq 0.01) \text { High significa } \\
* & (\mathrm{P} \leq 0.05) \text { significant } \\
\pm & \text { Standard deviation }\end{array}$ & & & \\
\hline
\end{tabular}

The oestrogen and progesterone levels were highly significant $(\mathrm{P} \leq 0.01)$ increased during the green season than the dry one (Table, 1$)$.

The follicular fluid total protein level was high significant increased while albumin was significant increased during the green season, when compared to those of the dry one (Table I).

Inorganic phosphorus and calcium levels in the follicular fluid during the oestrogenic stage were significantly increased during the dry season when compared to the green one (Table 3).

Manganese, Iron, Zinc and copper levels were significant increased during the green season than the dry one. (Table 3).

\section{Transaminase enzymes (AST \& ALT):}

As shown from table (2) the AST \& ALT levels were significantly increased during the dry season than the green one in the follicular fluid (oestrus phase).

\section{DISCUSSION}

\section{Oestrogen and progesterone:}

The follicular fluid plays a major role in ovarian physiology including steriodogenesis, oocyte maturation and ovulation Edwards, (1974), while, Younis et al. (1988) and Eissa, (1995) mentioned that the follicular fluid is in close contact with the oocyte and granulose cells, so alterations in the concentration of its different constituents may reflect the requirements of follicular structure. This supported our obtained 
results which showed a high significant increase in the follicular oestrogen and progesterone levels during the (oestrus phase) in the green season than the dry one due to good quality and quantity of nutrition and temperature. Also, this result was in agreement with Rone et al. (1983) and Naveed Khan et al. (2005) who added that the follicular growth and nutrition play a role in follicular estradiol production. These results were in agreement with Lamming, et al. (1979); Arthue et al. (1982) and Younis (1995) who observed that the steroids had a significant increase during oestrus phase than other phases and during the green season than the dry one. On the others hand, Mekkway, et al. (1988) obtained a lower follicular oestradiol concentration levels $143.24 \pm 19.5 \mathrm{ng} / \mathrm{ml}$ in large follicles and $946.93 \pm 3.83 \mathrm{ng} / \mathrm{ml}$ in small sized follicles during the dry season. The variations may be due to nutrition, age, size of follicles and environmental factors. While Gerrard et al. (2002) and Nandis et al. (2007) supported our results and cited that the larger the size of follicle the more steroid was detected in the follicular fluid.

\section{Total protein, albumin and globulin:}

The results of this study showed that, the follicular fluid total protein level was highly significant $(\mathrm{P}<0.01)$ increased in the follicular fluid of the cyclic buffalo cows (oestrus phase) during winter than summer due to the effect of season and nutrition. This result is in agreement with Nasr, et al. (1965) who explained the increase of total protein by the marked metabolic activity of the body under the oestrogenic effect. The higher concentration of total protein in preovulalory follicle of buffaloes may be due to the stretched pore phenomenon Parving, (1975).

Younis (1995) demonstrated that the serum total protein of buffalo cows during oestrus phases was $10.26 \pm 0.46 \mathrm{gm} / \mathrm{dl}$ during the green season and $9.39 \pm 0.57 \mathrm{gm} / \mathrm{dl}$ during the dry one, the increase was highly significant during the green season than the dry one.

Abdel- Raheim (1982) found an increase in the serum total protein level of fertile buffalo-cows and during the green season than the dry one, may be due to age, feeding and season. Lipner (1988) added in the same direction and reported that the follicular fluid constituents were similar to blood plasma Nandis et al. (2007) supported our results and proved that, the total protein concentration increased as follicles became larger.

The study showed a significant increase in globulin level during the green season than the dry one. 
The obtained results were in agreement with Abd El-Aziz et al., (2001) who found albumin and globulin levels were significantly high in the follicular fluid of normal buffaloes in the green season.

\section{Transaminases (AST \& ALT):}

The obtained results revealed a significant increase $(\mathrm{P}<0.05)$ in AST \& ALT concentrations in the follicular fluid during the oestrus phase in cyclic buffaloes in the dry season than the green one. Edwrds (1974) supported our results and mentioned that, the transaminases rise as the follicle developed, while McNatty (1978) found a wide range of enzyme within the follicular fluid which have intracellular function.

On the other hand Abbas et al. (2002) found a lower levels in AST $(8.2 \pm 0.1 \mathrm{U} / \mathrm{L})$ and ALT $(21.2 \pm 0.3 \mathrm{U} / \mathrm{L})$ in the follicular fluid of the large follicles of buffaloes during oestrus phase. Younis (1995) supported our findings and demonstrated a significant increase in serum AST\&ALT levels in buffalo-cows during oestrus phases in summer than winter. The variations may be due to nutrition and climatic conditions.

\section{Inorganic phosphorus and calcium:}

The obtained results revealed a significant increase in inorganic phosphorus level in the follicular fluid of cyclic buffaloes during the dry season than the green one. These findings were in agreement with Eissa (1995) who found a high level of inorganic phosphorus $(5.32 \pm 1.34$ $\mathrm{mg} / \mathrm{dl})$ and calcium level $(10.51 \pm 2.5 \mathrm{mg} / \mathrm{dl})$ in the follicular fluid of buffalo-cows during oestrus phase in summer season and stated that, the follicular concentrations of calcium and inorganic phosphorus increased profoundly during the earlier days of oestrus cycle. McDonald (1980) demonstrated that, the higher level of serum phosphorus during oestrus phase may be due to the increased metabolic activity under the oestrogenic effect, while Nandis et al. (2007) showed that, the calcium and inorganic phosphorus levels increased in the follicular fluid as the follicular size increased.

\section{Manganese, iron, zinc, and copper:}

The obtained results showed a high significant increase in manganese level and a significant increase in iron, zinc and copper levels concentrations in the follicular fluid of oestrus phases of buffaloes during the green season than the dry one. These results are in agreement with El-Enany (1994) who mentioned that, the serum level of manganese and iron in fertile buffaloes was increased by feeding on high quality of green fodders or to effect of day light period, temperature or humidity, the significant increase in follicular fluid zinc during oestrus 
may be attributed to oestrogen anabolic effect and increased prostaglandins which bind zinc Song and Adam, (1978).

Some zinc involvements may be mediated by influences on pituitary gonadotropin production Yarmol 'Chuck., et al. (1979).

The increased level of copper during oestrus phase may be due to the effect of oestrogen which induces the synthesis of ceruplasmin (copper containing globulin of blood plasma) Brandes, et al. (1980).

Our findings agreed with the result of Osman, et al. (1979) and El-Enany (1994) who found the higher levels of serum manganese, zinc and copper in the green season than in the dry one. The level of nutrition on green fodders and climatic conditions during winter season play an important role in significant increase and may be responsible for the difference.

It could be concluded that, the nutrition on green fodders and climatic conditions during the green season play an important role in variable significant increases in hormonal and mineral constituents of the follicular fluid during oestrus phase in buffalo- cows. Consequently the fertility rate will be increased.

\section{REFERENCES}

Abbas, H.E. (1998): Investigations on in -vitro gertolization in buffaloes. Ph. D. Thesis, Fac. Vet. Med. Zagazig University.

Abbas, H.E.; Youssef, R.H. and Rahmy Nariman, A. (2002): Relationship between chemistry of follicular fluid, histolical signs of ovaries and in - vitro maturation of buffalo occytes during different stages of predicting estrus cycle. In press.

Abd El-Aziz, M.Z.; Mona, M.H.; Alaa El-Deen and Samira, A. Emara (2001): Alterations of some biochemical parameters and enzymes in follicular fluid of buffalo - cows suffered from cystic ovaries. J. Egypt. Vet. Med. Assoc. 61, No.6c: 77-87.

Abdel-Raheim, A.A. (1982): studies on some serum constituents in fertile and infertile cows and buffaloes. Assuit Vet. Med. J. 10. 19: 101.

Abraham, G.E (1977): "Handbook of Radioimmunoassay" vol.5.pp551556, Marcel Dekker, clinical and Biochemical Analysis. Inc. California 20770 Leapwood. Ave.Carson.

Agthe, O. and Kolm, H.P. (1975): Zuchthyg. 10, 16- 23.

Arthur, G.H.; Noaks, D.E. and Pearson, H. (1982): Veterinary Reproduction and obstetrics $4^{\text {th }}$. Ed. Bailliere Tindall, London. 
Bellin, M.E. and Axis, R.L. (1984): Chondrotin sulfate and indicator of atresia in bovine follicles. Endocrinal., 144: 428-434.

Brandes, J.M.; Lightman, A.; Its Kovity, J. and Zinder, O. (1980): Zinc concentration in gravidas serum and amniotic fluid during normal pregnancy. Biol. Neonat., 38: 66.

Edwards, R.G. (1974): Follicular fluid. J. Reprod. Fertile. 37: 189-219.

Eissa, M.tl. (1995): Concentrations of steroids and biochemical constituents in follicular fluid of buffalo-cows during different stages of oestrus cycle. Vet. Med. J. Vol.43, No. 1: 147-155.

El-Enany, G.M.S. (1994): Some biochemical studies of blood serum in fertile and infertile bovines. A thesis, Zag. Univ., M.Vet. Med. Sci. Obst., Gyn. And A.1. Dept.

El-Sawaf, S. and Schmidt, K. (1962): Morphological changes in normal and abnormal ovaries of buffaloes with special references to their function, Vet. Med. J., 8: 249-273.

El-Shawaf, A.M.A. (1979): Clinical investigation for the infertility problems in Dakahlia province in cattle and buffaloes. M.V.Sc. Thesis, Fac. Vet. Med. Zag. Univ.

El-Wishy, A.B. (1965): Some clinical studies on diagnosis of pregnancy and infertility in buffalo - cows and possible treatment. M.D. Vet. Thesis, Fac. Vet. Med. Cairo Univ.

Fraser, D.; Jones, G.; Kooh, S.W. and Raddle, I.C. (1987): Calcium and phosphate metabolism. In: Fundamentals Clinical Chemistry. $3^{\text {rd }}$. Ed., pp. 705-728. ed. N.W. Tietz. Philadelphia: W.B. Saunders Company.

Gerard, N.; Lonseaus., Duchamn G. and Seguin, F. (2002): Analysis of the variations of follicular fluid composition during follicular growth and maturation in the mare using proton nuclear magnetic resonance (IHNMR). Equipe Reproduction Equine, PRC, INRA - Haras Nationaux 37380 Nouzilly, France gerard @ tours. Inra. Fr. 1: Reproduction 2002 Aug; 124 (2): 241.

Gharib, H.M.; Goher, M.E.; El-Sawaf, S. and Schmidt, K. (1964): Some studies on the role by the environmental variations on infertility in buffaloes and imported cows in Egypt. Vet. Med. J. Cairo Univ. No. 11: 233 - 243.

Grant, G.H.; Silverman, L.M. and Christenson, R.H. (1987): Aminoacids and proteins. In: Fundumenta 15 Clinical Chemistry. $3^{\text {rd }}$ Ed., pp. 291-345, ed. N. W. Tietz. Philadelphia: W.B. Saunders. 
Henery, R.J. (1965): Clinical chemistry, principles and techniques. Harper and Row. Inc. New York, N.Y.

Hutchuson, J.S. (1993): Controlling reproduction. Published by Chapman and Hall, London. Glasgow. New York.

Kanchev, L.N.; Dobson, H.; Ward, W.R. and Fitzpatrick, R.J. (1976): Concentration of steroids in bovine peripheral plasma during the oestrus cycle and the effect of betamethasone treatment. J. Reprod. Fert. 48: 341-345.

Lamming, G.E.; Foster, J.P. and Bulman, D.C. (1979): pharmacological control of reproduction cycles. Vet. Rec. 24, 165.

Lipner, it (1988): Mechanism of mammalian ovulation. Edited by Knobil E. Nill, Vol.1, Raven Press. New York.

Mc Natty, K.P. (1978): Follicular fluid in the vertebrate ovary. By Richard, E. Jonesa, Plenum press, New York.

McDonald, L.E. (1980): Veterinary Endoc and Reprod. $3^{\text {rd }}$. Ed. Lea and Febiger Phil.

Mekkawy, M.Y.; Salem, H.A.; Younis, M.; Youseef, R.; Afaf, Azouuz and Farahat, A.A. (1988): Estradiol, progesterone, thyrotrophic (TSH) and thyroid hormones concentrations of buffalo follicular fluid in relationship to follicle size. Alex. J. Vet. Sci. 4(2): 89-194.

Meret, S. and Henkin, R.T. (1971): Simultaneous direct estimation of atomic absorption spectrophotometrics of copper, zinc and iron in serum, urine and cerebrospinal fluid. Clin. Chem. 17(5): 369-370.

Nandis, Kumar V.G.; Maniunatha, B.M., and Gupta, P.S. (2007): Biochemical composition of ovine follicular fluid in relation to follicle size. National Institute of Animal to Nutrition and physiology Adugodi, Bangalore, India. Dev. Growth Differ. Jan 49 (1): 61 Frivate.

Nasr, H.; Soliman, F.A.; Abdo, M.S. and Nazier, H. (1965): Total gonadotrophic, thyrotrophic (TSH) and adrenocorticotrophic hormone (ACTH) content of pituitaries of buffaloes affected with some ovarian abnormalities. Vet. Med. J. Giza, 12: 387 390.

Naveed Khan - Sabir, Md, and Bruce R. Carr, MD (2005): The normal menstrual cycle and the control of ovulation. index contributers search, last Reviewers 1 March 2005. 
Osman, A.M.; Allam, F. and Farrag, A.A. (1979): Variations in some of the blood constituents of cattle during the oestrus cycle and ovarian inactivity. J. Egypt. Vet. Med. Assoc. 14(4): 89.

Parving, H.H. (1975): Microvascular permeability to plasma proteins in hypertension and diabetes mellitus in man on the pathogenesis of hypertensive and diabetic microangiopathy. Thesis, the University of Copenhagen.

Perry, S. (1969): Cited by El-Shawaf, A.M.M.A. 1979, Clinical investigations for the infertility problems in Dakahlia province in cattle and buffaloes. M.B. Sci. Thesis, Fac. Vet. Med., Zag. Unive.

Rone, J.D.; Henricks, M. and EchternKamp, S.E. (1983): The effect of energy intake on ovarian follicular development and steroid secretion in the young suckled beef Cow. Biol. Reprod. 28 (suppl.1): 386.

Sendecor, G.W. and Cochran, W. (1980): Statistical method. $7^{\text {th }}$. Ed. lowa state Univ. U.S.A.

Sharawy, J.M. (1977): Some studies on the utero-ovarian relationship in the clinically non-pregnant Egyptian buffaloes during oestrus cycle. M.V. Sci. Fac. Vet. Med. Zagazig Univ.

Song, M.K. and Adam, N.F. (1978): Role of prostaglandin E in zinc absorption in the rate. Amer. J. Physiol. 234: 44.

Yarmol' Chuck, H.M. and Meschyshen, I.F. (1976): The effect of corticotrophin, Somatotropin and thyrotropin on the distribution of mineral substances in the tissues of hypophysectomized rats. UKR biokhim. Zh. No. 4:517.

Younis, M.; Salem; H.A.H.; Wasfy, M.; Afaf Azouz and Farahat, A.A. (1988): Alterations of some parameters in follicular fluid in relation to follicular size. V36 (2): 287-296.

Younis, S.S. (1995): Studies on some reproductive problems in bovine. A thesis, Zagazig univ. Ph. D., Obs., Gynae. and A.I. 